\title{
Muskel- og skjelettplager og fremtidig sykefravær
}

\begin{abstract}
Sammendrag
Bakgrunn. Muskel- og skjelettlidelser utgjør den største diagnosegruppen med sykepengeutbetaling hvert år. Vi har undersøkt hvordan muskel- og skjelettplager predikerer høyt sykefravær generelt, også når man tar hensyn til andre individuelle variabler $\mathrm{i}$ en normalbefolkning i alderen 40-45 år.
\end{abstract}

Materiale og metode. Studien omfatter svar fra 14058 kvinner og menn i alderen 40-45 år bosatt i Hordaland som deltok i Helseundersøkelsen i Hordaland 1997-99. Vi har hatt tilgang til sykepengedata fra Forløpsdatabasen trygd (FD-trygd) fra seks måneder etter helseundersøkelsen og ut året 2004. En samlet utbetaling av over 40 sykepengedager fra folketrygden ble regnet som høyt sykefravær.

Resultater. $41 \%$ av respondentene oppga at de hadde hatt smerter og/ eller stivhet fra muskler og ledd i minst tre måneder året før helseundersøkelsen. Kvinner, personer med lav utdanning, de med psykiske plager og dårlig egenvurdert helse, og de som ikke drev hard mosjon, var mest plaget av muskel- og skjelettsmerter og hadde størst forekomst av høyt sykefravær. Personer med langvarige muskel- og skjelettplager hadde en høyere risiko for senere høyt sykefravær etter kontroll for andre individuelle faktorer (OR 1,9; $95 \%$ KI 1,7-2,0). Risikoen var spesielt høy blant dem med utbredte smerteplager.

Fortolkning. Muskel- og skjelettplager synes å være en uavhengig prediktor for fremtidig høyt sykefravær.
Artikkelen er basert på en særoppgave ved Det medisinske fakultet, Universitetet i Bergen, 2007 (26)

> Se også side 1208
Ingrid Andersen*

Hanne Frydenberg*

Det medisinske fakultet

Universitetet i Bergen

John Gunnar Mæland

john.meland@isf.uib.no

Institutt for samfunnsmedisinske fag Universitetet i Bergen

Kalfarveien 31

5018 Bergen

\section{*Nåværende adresse: \\ I. Andersen, Stord sjukehus \\ 5409 Stord}

H. Frydenberg, Nordlandssykehuset 8092 Bodø

De fleste undersøkelser har konkludert med multifaktorielle forklaringer på sykefravær (1). Når man skal lete etter årsaker til sykefravær, bør det skilles mellom forhold på makronivå som kan forklare omfanget av sykefravær i samfunnet, som arbeidsliv, trygdesystem, legers holdninger etc., og faktorer på mikronivå som er viktige for å forklare hvem som blir sykmeldt. Dette omfatter individuelle faktorer som kjønn, alder, sosial bakgrunn, helseforhold, type arbeid osv. I denne artikkelen har vi valgt å se på faktorer på mikronivå.

Muskel- og skjelettplager har i flere studier vist seg å ha betydning for langtidssykefravær $(2-6)$. Vi har imidlertid funnet få studier som har tatt hensyn til hvor stor betydning muskel- og skjelettplager har for høyt sykefravær, når det tas hensyn til andre faktorer, som kjønn, utdanning, levevaner og andre helseproblemer.

Smerter fra muskel- og skjelettapparatet er utbredt $\mathrm{i}$ den voksne befolkningen. Også i Helseundersøkelsen i Hordaland ble det funnet høy forekomst av muskel- og skjelettplager blant 40-45-åringer, med tydelige kjønnsforskjeller i forekomst og utbredelse (7). Vi har knyttet dette materialet opp til registrerte sykepengeutbetalinger fra folketrygden i tiden etter helseundersøkelsen. Hensikten var å se hvordan muskel- og skjelettplager predikerer høyt sykefravær når vi tar hensyn til andre individuelle faktorer.

\section{Materiale og metode}

Helseundersøkelsen i Hordaland (HUSK) ble utført i 1997-99 i samarbeid med Statens helseundersøkelser, Universitetet i Bergen og kommunehelsetjenesten i Hordaland (7). Studiepopulasjonen inkluderte alle indi- vider født 1953-57 bosatt i Hordaland, og omfattet i utgangspunktet 25630 personer, hvorav 22232 møtte frem til undersøkelse og fylte ut et spørreskjema - skjema 1. De fremmøtte fikk med seg et nytt spørreskjema som skulle fylles ut hjemme - skjema 2. Det var 16080 personer som returnerte skjema 2 , et frafall på $27,7 \%$. Vi har tatt utgangspunkt i dem som svarte positivt i skjema 2 på at de var i lønnet arbeid og som ga opplysninger om smerter/stivhet, dvs. 14058 personer. HUSK ble tilrådd av den regionale komité for medisinsk forskningsetikk, Helseregion Vest og godkjent av Datatilsynet. Muskel- og skjelettplagene ble kartlagt ut fra spørsmålet: «Har du i løpet av det siste året vært plaget med smerter og/eller stivhet $\mathrm{i}$ muskler og ledd som har vart i minst tre måneder sammenhengende?» De som svarte «ja», ble bedt om å gi nærmere opplysninger om lokalisasjon, utbredelse, varighet, redusert aktivitet, redusert arbeidsevne og sykmelding pga. muskel- og skjelettsmertene. Vi slo sammen sju spørsmål som omfatter temaene nervøsitet og urolighet, angst, trygghet, irritabilitet, optimisme, depresjon og ensomhet til en variabel kalt «psykiske plager». I en skala der 7 var minimumsskår og 28 var maksimum, ble svarene gradert som «nei» (skår 7), «litt» (skår 8-14) og «mye» (skår 15-28) psykiske plager. I regresjonsanalysene ble variabelen psykiske plager delt inn i ja og nei, der ja ble definert som en skår > 12. Egenvurdert helse baserer seg på spørsmålet «Hvordan er helsen din nå?» Det var fire svarkategorier. Dette er det samme spørsmålet som er blitt brukt $i$ andre befolkningsundersøkelser i Norge de siste 20 årene (8). I den siste tabellen er egenvurdert helse delt opp i god og dårlig, der god tilsvarer «god» eller «svært god» og dårlig tilsvarer «ikke helt god» og «dårlig» helse. Fra HUSK-skjemaet hentet vi videre opplysninger om høyeste fullførte utdanning og

\section{Hovedbudskap}

- Langvarige muskel- og skjelettplager $\emptyset$ ker risikoen for langvarig sykefravær uavhengig av andre risikofaktorer

- Risikoen er størst ved utbredte smerteplager

- Smertevarighet og spesifikk lokalisasjon spiller mindre rolle for sykefraværsrisiko 
mosjonsvaner siste året, hvor respondentene anga antall timer per uke brukt til lett aktivitet $\mathrm{og}$ til hard fysisk aktivitet.

Oppfølgingsdata for sykefravær ut året 2004 er hentet fra Forløpsdatabasen - trygd (FD-trygd) som er et register i Statistisk sentralbyrå, omfatter hele befolkningen og inneholder opplysninger fra en rekke statistikkområder. Registeret omfatter bare fravær over 16 dager med noen få unntak (når trygden også dekker arbeidsgiverperioden). Vi har dessuten sett bort fra sykefraværet de første seks måneder etter HUSK-undersøkelsen. Høyt sykefravær er definert som samlet registrert sykepengeutbetaling $>40$ dager.

Vi har brukt statistikkprogrammet SPSS for Windows versjon 13.0 til bearbeiding av dataene. Logistisk regresjonsanalyse ble brukt til å analysere risiko for langtidssykefravær. Vi inkluderte følgende forklaringsvariabler i suksessive kumulative modeller: smerte/stivhet siste år (ja/nei); kjønn; utdanning (høyskole/universitet vs videregående/ grunnskole); psykiske plager (ja/nei); egenvurdert helse (god/dårlig). Mosjonsvaner (lett og hard) bidro ikke signifikant til å forklare langtidssykefravær $\mathrm{i}$ de multivariate modellene. Tosidig P-verdi $<0,05$ ble regnet som statistisk signifikant.

\section{Resultater}

Muskel-og skjelettplager

Samlet anga $41 \%$ av deltakerne å ha hatt langvarig smerte og/eller stivhet i muskler og ledd i minst tre måneder sammenhengende det siste året før helseundersøkelsen. Det var en større andel kvinner enn menn som var plaget av dette (tab 1). For både kvinner og menn var de med lavest utdanning og de som ikke drev hard mosjon, mest plaget av muskel- og skjelettsmerter. Lett mosjon hadde ingen signifikant innvirkning på smerte og stivhet. Blant dem som definerte sin egen helse som «dårlig» eller «ikke helt god», var det klart høyere forekomst av smerter enn hos dem som regnet helsen sin for å være «svært god». Langvarig smerte eller stivhet i muskel- og skjelettsystemet var også klart forbundet med omfanget av psykiske plager.

\section{Høyt sykefravær}

Det ble registrert samlet sykepengeutbetaling $>40$ dager i oppfølgingsperioden blant $31,5 \%$ av deltakerne. En større andel kvinner enn menn hadde høyt sykefravær (tab 1). De med lavest utdanning, de som ikke drev hard mosjon og de som definerte sin egen helse som dårlig eller ikke helt god, hadde størst forekomst av høyt sykefravær. Graden av lett mosjon hadde mindre, men statistisk signifikant sammenheng med høyt sykefravær. Blant personene med psykiske plager var andelen med høyt sykefravær klart høyere enn blant personene uten psykiske plager og denne andelen økte med graden av psykiske plager.

\section{Høyt sykefravær}

og muskel-og skjelettplager

De som svarte ja på spørsmålet om langvarig smerte/stivhet, hadde nær dobbelt så høy forekomst av høyt sykefravær enn de som som ikke var plaget av smerte/stivhet (tab 2).

Blant dem som oppga langvarig smerte/ stivhet, ble det ikke påvist noen sammenheng mellom lokalisering av smerteplagene og høyt sykefravær (data ikke vist). Det ble derimot funnet en korrelasjon mellom antall smertelokalisasjoner og høyt sykefravær. Det ble ikke påvist noen statistisk signifikant forskjell i høyt sykefravær ut fra varighet av plagene før smerten/stivheten hadde vart over 8,5 år. Av dem som oppga å ha redusert aktivitet pga. plagene, hadde $48 \%$ høyt sykefravær, mot $35 \%$ av dem som ikke hadde redusert aktivitetene. Høyt sykefravær var større blant dem som mente at arbeidsevnen i «betydelig grad» var påvirket sammenliknet med dem som mente smerte- ne hadde «ubetydelig» påvirkning på arbeidsevnen. Av dem som oppga at de tidligere hadde vært sykmeldt pga. muskel- og skjelettplager, ble $59 \%$ registrert med høyt sykefravær i oppfølgingsperioden.

\section{Multivariate analyser}

For personer som oppga smerter/stivhet i minst tre måneder, var ujustert oddsratio (OR) for høyt sykefravær 2,27 (95\% KI 2,11-2,44). Med alle forklaringsvariabler inkludert var oddsen for høyt sykefravær, gitt muskel- og skjelettplager fremdeles, nær fordoblet (OR 1,85, $95 \%$ KI 1,71-2,00) (tab 3). Uavhengig av muskel- og skjelettplager var det økt risiko for høyt sykefravær for kvinner sammenliknet med menn. Risikoen var også høyere for personer med lav utdanning og hos dem med dårlig egenvurdert helse. De øvrige variablene bidro omtrent like mye til å redusere effekten av muskel- og skjelettplager på sykefraværet.

Tabell 1 Andel med smerte/stivhet minst tre måneder siste år og andel med høyt sykefravær (> 40 sykepengedager fra folketrygden) i oppfølgingsperioden etter kjønn, utdanning, mosjonsvaner, psykiske plager og egenvurdert helse

\begin{tabular}{|c|c|c|c|c|c|}
\hline & Antall (\%) & $\begin{array}{c}\text { Andel med smerte/ } \\
\text { stivhet siste } \\
3 \text { måneder } \\
(\%)\end{array}$ & P-verdi & $\begin{array}{l}\text { Høyt sykefravær } \\
\text { i oppfølgings- } \\
\text { perioden } \\
(\%)\end{array}$ & P-verdi \\
\hline Kjønn & & & $<0,001$ & & $<0,001$ \\
\hline Mann & $6777(48,2)$ & 36,5 & & 24,2 & \\
\hline Kvinne & $7281(51,8)$ & 45,3 & & 38,2 & \\
\hline Utdanning & & & $<0,001$ & & $<0,001$ \\
\hline Grunnskole & $2347(16,7)$ & 47,6 & & 41,2 & \\
\hline Videregående & $6472(46)$ & 43,9 & & 33 & \\
\hline $\begin{array}{l}1-3 \text { år høyskole/ } \\
\text { universitet }\end{array}$ & $2758(19,6)$ & 34,7 & & 26,8 & \\
\hline $\begin{array}{l}\text { 4+ år høyskole/ } \\
\text { universitet }\end{array}$ & $2481(17,6)$ & 34,7 & & 23,3 & \\
\hline Hard mosjon, timer per & & & $<0,001$ & & $<0,001$ \\
\hline Ingen & $3722(27,3)$ & 44,9 & & 34,8 & \\
\hline$<1$ & 3821 (28) & 39,3 & & 31,1 & \\
\hline $1-2$ & $4125(30,2)$ & 39 & & 29,8 & \\
\hline $3+$ & $1982(14,5)$ & 39,9 & & 28,2 & \\
\hline $\begin{array}{l}\text { Lett mosjon, timer per } \\
\text { uke }\end{array}$ & & & 0,589 & & 0,017 \\
\hline Ingen & $536(3,9)$ & 41,2 & & 32,3 & \\
\hline$<1$ & $1955(14,3)$ & 42,1 & & 34,3 & \\
\hline $1-2$ & $5242(38,3)$ & 40,4 & & 30,5 & \\
\hline $3+$ & $5967(43,6)$ & 41,2 & & 31 & \\
\hline Psykiske plager & & & $<0,001$ & & $<0,001$ \\
\hline Nei & $1192(9,1)$ & 28,2 & & 27,5 & \\
\hline Litt & $10824(82,9)$ & 39,9 & & 35,0 & \\
\hline Mye & $1033(7,9)$ & 60,4 & & 44,6 & \\
\hline Egen helse & & & $<0,001$ & & $<0,001$ \\
\hline Dårlig & $65(0,5)$ & 76,9 & & 41,5 & \\
\hline Ikke helt god & $1480(10,6)$ & 78,4 & & 52,8 & \\
\hline God & $9276(66,5)$ & 42,2 & & 31,4 & \\
\hline Svært god & $3135(22,5)$ & 19,2 & & 21,3 & \\
\hline
\end{tabular}


Tabell 2 Andel med høyt sykefravær (> 40 sykepengedager fra folketrygden) i oppfølgingsperioden etter oppgitte muskel- og skjelettplager ved helseundersøkelsen

\begin{tabular}{|c|c|c|c|}
\hline & Prosent & $\begin{array}{c}\text { Høyt sykefravær } \\
\text { i oppfølgingsperioden } \\
{[\%]}\end{array}$ & P-verdi \\
\hline Smerte/stivhet minst 3 måneder siste år & & & $<0,001$ \\
\hline Ja & 41,1 & 42 & \\
\hline $\mathrm{Nei}$ & 58,9 & 24,1 & \\
\hline Antall kroppsområder med smerte/stivhet & & & $<0,001$ \\
\hline 1 & 21,7 & 29,9 & \\
\hline 2 & 22,2 & 37,9 & \\
\hline $3-4$ & 32,3 & 43,4 & \\
\hline $5+$ & 23,8 & 54,9 & \\
\hline Smertevarighet (år) & & & $<0,001$ \\
\hline$<4,5$ & 23,5 & 41 & \\
\hline $4,5-7,8$ & 29,1 & 40,1 & \\
\hline $7,9-8,5$ & 22,3 & 39,9 & \\
\hline$>8,5$ & 25,1 & 46,8 & \\
\hline Redusert aktivitet pga. plagene & & & $<0,001$ \\
\hline Ja & 52,6 & 47,9 & \\
\hline Nei & 47,4 & 35,3 & \\
\hline Redusert arbeidsevne pga. plagene & & & $<0,001$ \\
\hline Nei/ubetydelig & 40,6 & 30,2 & \\
\hline I noen grad & 44,5 & 48,2 & \\
\hline I betydelig grad & 12,6 & 57,2 & \\
\hline Vet ikke & 2,2 & 45,7 & \\
\hline Sykmeldt pga. plagene & & & $<0,001$ \\
\hline $\mathrm{Ja}$ & 29 & 59 & \\
\hline Nei & 70,3 & 33 & \\
\hline
\end{tabular}

Tabell 3 Risiko for høyt sykefravær (> 40 sykepengedager fra folketrygden) i oppfølgingsperioden. Logistisk regresjon. Justert oddsratio (OR) med $95 \%$ konfidensintervall (95\% KI)

\begin{tabular}{lccc} 
& OR & $95 \% \mathrm{KI}$ & P-verdi \\
\hline Smerte/stivhet & 1,85 & $1,71-2,00$ & $<0,001$ \\
\hline Kjønn & 1,83 & $1,70-1,98$ & $<0,001$ \\
Utdanning & 0,66 & $0,61-0,72$ & $<0,001$ \\
\hline Psykiske plager & 1,32 & $1,20-1,45$ & $<0,001$ \\
Egenvurdert helse & 1,89 & $1,68-2,12$ & $<0,001$
\end{tabular}

\section{Diskusjon}

Vi fant at muskel- og skjelettplager var en viktig prediktor for fremtidig sykefravær uavhengig av andre individuelle riskofaktorer. Å ha høy utdanning og å være mann minsket sannsynligheten for høyt sykefravær, mens dårlig egenvurdert helse og psykiske plager økte sannsynligheten.

\section{Muskel- og skjelettplager}

Smerter og plager fra muskel- og skjelettapparatet er meget utbredte blant voksne. Rundt halvparten av alle avsluttede sykepengeutbetalinger begrunnes med lidelser i muskel- og skjelettsystemet (9). Denne diagnosegruppen utgjør også i de andre nordiske landene en stor del av kostnadene ved sykefravær.

De fleste studier om sykefravær med fo- nelig kjønn og mottakelse av høyere kompensasjon var prediktorer for langvarig sykefravær (4). I en tredje undersøkelse ble det funnet sammenheng mellom sykefravær og smerter i nedre del av ryggen, høy alder og det å bo alene (5). For symptomer fra nakke og armer var risikoen for sykefravær høyere blant kvinner og dem som bodde alene. Jobbrelaterte faktorer som var assosiert med forekomsten av muskel- og skjelettsymptomer, var lik de som var assosiert med bruk av helsetjenester og sykefravær.

Mens man i mange tidligere studier har satt søkelyset på spesifikke muskel- og skjelettsymptomer, dreier vår studie seg i utgangspunktet om muskel- og skjelettplager generelt. De fleste studier er gjort med tanke på å finne risikofaktorer som kan predikere sykefravær som skyldes muskel- og skjelettplager. Våre funn viser at muskel- og skjelettplager er en risikofaktor for det totale sykefraværet, selv etter at risikofaktorer er tatt hensyn til. Vi har ikke funnet studier med liknende resultat. Dette kan også være fordi mange studier først og fremst har hatt fokus på arbeidslivsfaktorer og sett på varigheten av sykefraværet innenfor definerte yrkesgrupper $(11,12)$.

\section{Lokalisasjon og utbredelse}

Det var økt forekomst av høyt sykefravær uansett hvor muskel- og skjelettplagene var lokalisert. I en svensk undersøkelse ble det heller ikke funnet en klar sammenheng mellom langtidssykefravær og lokalisasjonsfordeling (13). Langtidsfraværet var det samme for dem med bare korsryggssmerter og dem med bare smerter i nakke og skulder, mens det å ha smerter i begge lokalisasjoner var assosiert med høyere risiko for langtidssykefravær. I Ullensaker-undersøkelsen fant man at lokaliserte ryggsmerter ikke predikerte langtidssykefravær fire år senere, mens ryggsmerter i kombinasjon med mer utbredte muskel- og skjelettplager gjorde dette (2).

Også i vår undersøkelse var det tydelig at risikoen for høyt sykefravær økte med antall smertelokalisasjoner. I den siste Ullensakerundersøkelsen fra 2004 fant man klar sammenheng mellom utbredelsen av muskel- og skjelettplager og funksjonelle problemer $\mathrm{i}$ dagliglivet (14). Dette indikerer at utbredelse av muskel- og skjelettplager er en viktigere prognostisk faktor enn smertevarighet eller spesifikk lokalisasjon.

\section{Kjønn}

Kvinner anga oftere langvarig smerte/stivhet og hadde oftere høyt sykefravær. Dette samsvarer med flere andre undersøkelser (7, 15-17). Kjønnsforskjellene kan skyldes at menn og kvinner har ulike yrker og er tilknyttet ulike næringer, har ulike belastninger og er utsatt for ulike krav på arbeidsplassen, men de kan også tenkes forklart med ulik sårbarhet for samme belastning (18). Hormonelle og reproduktive faktorer, som irregulær eller forlenget menstruasjons- 
syklus og hysterektomi, er blitt funnet å være assosiert med kroniske muskel- og skjelettplager (19).

\section{Utdanning}

Personer med høyere utdanning hadde mindre muskel- og skjelettplager enn de med lavere utdanning. Dette kan muligens forklares med at høyt utdannede har yrker som er mindre fysisk belastende. En annen forklaring kan være livsstilsforskjeller. De med høyere utdanning mosjonerer mer og lever sunnere. Dette påvirker også sykefraværet (20). Vi fant en klar og gradert økning i sykefravær med synkende utdanning, noe som også er funnet i mange andre undersøkelser. En norsk prospektiv observasjonsstudie viste f.eks. at lengre utdanning minsker risikoen for at arbeidstakere med kroniske korsryggssmerter blir uføretrygdet (21).

\section{Mosjon}

I motsetning til hva vi forventet, fant vi bare nokså små forskjeller i forekomsten av smerte/stivhet eller sykefravær ut fra oppgitte mosjonsvaner. Regelmessig mosjon og trening er antatt å kunne forebygge både muskel- og skjelettplager og sykefravær begrunnet i dette (1). Eriksen og medarbeidere fant høyere sykefravær blant hjelpepleiere som var fysisk inaktive (22). I en annen undersøkelse fant man at utøvelse av sport minst ti måneder i året senket risikoen for nakke- og skuldersymptomer, samt langvarig sykefravær som følge av dette (23).

Når våre funn ikke bekreftet en slik sammenheng, kan dette ha flere forklaringer. Mosjon og trening kan tenkes både å senke og øke sannsynligheten for å få plager fra muskel- og skjelettapparatet. Virkningen av mosjon kan videre tenkes å være avhengig av belastningene i yrkeslivet. Effekten av trening på sykefravær krever muligens temmelig høy intensitet (24).

\section{Øvrige helseplager}

Risikoen for høyt sykefravær økte med omfanget av psykiske plager og ved dårlig egenvurdert helse. Selv om det var en klar sammenheng mellom muskel- og skjelettplager og disse helseindikatorene, var det en klar effekt av langvarige smerter og stivhet også etter statistisk kontroll for nivå av psykiske plager og egenvurdert helse.

Psykiske lidelser står for omkring en seksdel av sykepengetilfellene i Norge (9) og forekomsten av psykiske plager er temmelig høy i befolkningen. Det er velkjent at det er en overlapping mellom fysiske og psykiske symptomer ved så vel kroppslige som psykiske lidelser. Det har vært hevdet at betydningen av psykiske lidelser for sykefravær og uførhet er undervurdert (25), men det er ofte vanskelig å si sikkert hvilken lidelse som er primær og hvilken som er sekundær ved komorbide tilstander.

\section{Svakheter og usikkerhet}

Helseundersøkelsen i Hordaland er basert på selvrapporterte helseplager og ikke på diagnoser stilt av leger. Vi vet følgelig ikke hva som ligger til grunn for deltakernes angivelser av subjektive helseplager. Smerter og/ eller stivhet i muskler og ledd kan skyldes sykdommer med ulik alvorlighetsgrad, også sykdommer som ikke er relatert til muskelog skjelettsystemet, f.eks. kreft.

Ikke alle svarte på spørreskjema 1 og 2 Disse samt de som ikke bekreftet at de var i lønnet arbeid, ble utelatt fra analysene. Vi vet ikke hva dette frafallet innebærer i form av skjevhet. Prevalenstallene må derfor anses som usikre, men det er grunn til å tro at de påviste sammenhengene er valide.

Vi valgte å definere høyt sykefravær som mer enn 40 sykepengedager fra folketrygden i oppfølgingsperioden. Det reelle tallet sykefraværsdager kjenner vi ikke, fordi FDtrygd ikke registrerer sykepenger dekket av arbeidsgiver. De med høyt sykefravær etter denne definisjonen, har minst 56 dagers reelt sykefravær hvis dette bare omfatter en sammenhengende sykmelding, og lengre fravær hvis det skyldes flere sykmeldingsepisoder.

Vår metode for å måle omfanget av psykiske plager representerer ikke noen validert skala, men gir antakelig et adekvat bilde av grad av symptombelastningen. Vi hadde bare et begrenset antall potensielle konfunderere med i denne undersøkelsen. Det hadde f.eks. vært ønskelig å inkludere opplysninger om arbeidsforholdene. Arbeidsmiljøet kan medføre sykdom som fører til fravær, men arbeidsmiljøforhold kan også senke terskelen for når fravær blir et resultat av sykdom. Også andre livsstilsfaktorer enn fysisk aktivitet, som røyking og overvekt, er forbundet med både muskel- og skjelettplager og sykefravær $(20,22)$. Slike faktorer bør inngå i fremtidige undersøkelser.

Vi takker Arnstein Mykletun for tilrettelegging av data for analysene.

\section{Oppgitte interessekonflikter: Ingen}

\section{Litteratur}

1. Ose SO, Jensberg H, Reinertsen RE et al. Sykefravær. Kunnskapsstatus og problemstillinger. SINTEF-rapport A325. Trondheim: SINTEF Helse, 2006

2. Natvig B, Eriksen W, Bruusgaard D. Low back pain as a predictor of long-term work disability. Scand J Public Health 2002: 30: 288-92.

3. Kuijer W, Brouwer S, Preuper HR et al. Work status and chronic low back pain: exploring the International Classification of Functioning, Disability and Health. Disabil Rehabil 2006; 28: 379-88.

4. Steenstra IA, Verbeek JH. Heymans MW et al. Prognostic factors for duration of sick leave in patients sick listed with acute low back pain: a systematic review of the literature. Occup Environ Med 2005; 62: 851-60.

5. IJzelenberg W, Burdorf A. Risk factors for musculoskeletal symptoms and ensuing health care use and sick leave. Spine 2005; 30: 1550-6.

6. Hansson T, Jensen I. Swedish Council on Technology Assessment in Health Care (SBU). Chapter 6. Sickness absence due to back and neck disorders. Scand J Public Health 2004; (suppl 63): 109-51. http://sjp sagepub com/cgi/reprint/32/5/109 (5.8.2008).

7. Sirnes E, Sødal E, Nurk E et al. Forekomst av mus kel- og skjelettplager i Hordaland. Tidsskr Nor Lægeforen 2003: 123: 2855-9.

8. Schou MB, Krokstad S, Westin S. Hva betyr selvopplevd helse for dødeligheten? Tidsskr Nor Lægeforen 2006; 126: 2644-7.

9. Opdalshei OA. Diagnoser og sykefravær 1994-1999. RTV rapport 04/2000. Oslo: Utredningsavdelingen, Rikstrygdeverket, 2000 www.nav.no/binary/1073745937/file (16.6.2008)

10. Ekman M, Johnell O, Lidgren L. The economic cost of low back pain in Sweden in 2001. Acta Orthop 2005; 76: 275-84.

11. Burdorf A, Naaktgeboren B, Post W. Prognostic factors for musculoskeletal sickness absence and return to work among welders and metal workers. Occup Environ Med 1998: 55: 490-5.

12. Bergström G, Bodin L, Bertilsson $\mathrm{H}$ et al. Risk fac tors for new episodes of sick leave due to neck or back pain in a working population. A prospective study with an 18-month and three-year follow-up. Occup Environ Med 2007; 64: 279-87.

13. Nyman T, Grooten WJ. Sickness absence and con current low back and neck-shoulder pain: results from the MUSIC-Norrtälje study. Eur Spine J 2007; 16: 631 -8. Rettelse: Eur Spine J 2007: 16: 639-40.

14. Kamaleri Y, Natvig B, Ihlebaek CM et al. Localized or widespread musculoskelatal pain: Does it matter? Pain 2008; 138: 41-6.

15. Brage S, Nygård JF, Tellnes G. The gender gap in musculoskeletal-related long-term sickness absence in Norway. Scand J Soc Med 1998; 26: $34-43$

16. Gjesdal S, Bratberg E. The role of gender in longterm sickness absence and transition to permanent disability benefits. Results from a multiregister based, prospective study in Norway 1990-1995 Eur J Public Health 2002; 12: $180-6$.

17. Wijnhoven HA, de Vet HC, Picavet HS. Prevalence of musculoskeletal disorders is systematically higher in women than in men. Clin J Pain 2006; 22 : $717-24$

18. Mæland JG, Haugland S. Det syke kjønn? Sykelighet blant kvinner og menn i Norge. I: Schei B, Bak keteig LS, red. Kvinner lider - menn dør. Folkehelse i et kjønnsperspektiv. Oslo: Gyldendal Akademisk, 2007: 69-87.

19. Wijnhoven HA, de Vet HC, Smit HA et al. Hormonal and reproductive factors are associated with low back pain and chronic upper extremity pain in women - The MORGEN study. Spine 2006; 31 : $1496-502$.

20. Allebeck P, Mastekaasa A. Swedish Council on Technology Assessment in Health Care (SBU). Chapter 5. Risk factors for sick leave: general studies. Scand J Public Health 2004; (suppl 63): 49-108. http://sjp.sagepub.com/cgi/reprint/32/5/ 49 (5.8.2008)

21. Hagen KB, Holte HH, Tambs K et al. Socioeconomic factors and disability retirement from back pain: a 1983-1993 population-based prospective study in Norway. Spine 2000; 25: 2480-7.

22. Eriksen W, Bruusgaard D. Physical leisure-time activities and long-term sick leave: a 15-month prospective study of nurses' aides. J Occup Environ Med 2002; 44: 530-8.

23. van den Heuvel SG, Heinrich J, Jans MP et al. The effect of physical activity in leisure time on neck and upper limb symptoms. Prev Med 2005; 41 $260-7$

24. Proper KI, van den Heyvel SG, de Vroome EM et al. Dose-response relation between physical activity and sick leave. Br J Sports Med 2006: 40: $173-8$.

25. Mykletun A, Øverland S. Mentale lidelser undervurderes som årsak til uføretrygding. Tidsskr Nor Lægeforen 2006; 126: 1491-2

26. Andersen I, Frydenberg H. Hvilken betydning har muskel- og skjelettplager for langtidssykefravær? En studie basert på Helseundersøkelsen i Hordaland. Særoppgave, våren 2007. Bergen: Det medisinske fakultet, Universitetet i Bergen, 2007.

Manuskriptet ble mottatt 11.1. 2008 og godkjent 26.3. 2009. Medisinsk redaktør Erlend Hem. 